\title{
A NOTE ON THE MISINTERPRETATION OF SECTION 13 OF THE TRUST PROPERTY CONTROL ACT: A PROPOSED SOLUTION
}

\section{Introduction}

Section 13 of the Trust Property Control Act (57 of 1988 hereinafter "the TPCA") has received much judicial attention in recent times. Several applications in terms of section 13 of the TPCA related to amending a trust provision contained in a charitable bequest which allegedly conflicted with constitutional principles. Consequently, section 13 attained a constitutional dimension. The judgments can be commended for the manner in which our courts have attempted to strike a balance between the various constitutional rights at stake in such matters. However, the note (this contribution forms part of an LLD thesis titled The South African Law of Trusts with a view to Legislative Reform (2016)) will reveal that our courts have at times misinterpreted the criterion of section 13 in its attempt to address the constitutional arguments put forth. The note will highlight the content and depth of section 13. Thereafter, the focus will shift to the constitutional dimension attained by the provision with particular reference to charitable trusts, followed by a discussion of the manner in which the provision has been interpreted by our courts. The aim of the note is to provide a workable solution that will give effect to the method in which the provision is currently being interpreted and strike a balance between the constitutional rights at play.

\section{Section 13 of the Trust Property Control Act}

Section 13 was incorporated in the TPCA as a consequence of the recommendation made by the South African Law Reform Commission (SALRC) in its Report on trusts (South African Law Commission Project 9: Report on the review of the Law of Trusts June 1987 (hereinafter "the SALRC Report"). In its report the SALRC recommended that courts' not be vested with wide powers in respect of the variation of trust provisions and that the rights of the founder, trustee and beneficiaries to vary a trust remain unchanged (SALRC Report 48). It was further suggested that the courts' common law power to vary trust provisions be extended to all cases where the provisions of the trust instrument results in consequences which the founder did not contemplate or foresee and which hamper the achievement of the objects of the founder or prejudice the interests of beneficiaries or are in conflict with the public interest (SALRC Report 48).

These recommendations were incorporated in section 13 which reads as follows: 
"If a trust instrument contains any provision which brings about consequences which in the opinion of the court the founder of a trust did not contemplate or foresee and which-

(a) hampers the achievement of the objects of the founder; or

(b) prejudices the interests of beneficiaries; or

(c) is in conflict with the public interest,

the court may, on application of the trustee or any person who in the opinion of the court has a sufficient interest in the trust property, delete or vary any such provision or make in respect thereof any order which such court deems just, including an order whereby particular trust property is substituted for particular other property, or an order terminating the trust."

The provision allows for the amendment of trust provisions by the High Court. It does not however, replace the High Court's common-law power of amendment and instead supplements it (Du Toit South African Trust Law 2ed (2007) 53), by broadening the court's power to not only vary trust provisions, but to terminate the trust as well (Cameron, De Waal, Wunsh, Solomon and Kahn Honoré's South African Law of Trusts 5ed (2002) 517). In Conze v Masterbond Participation Trust Managers (Pty) Ltd (1996 (3) SA 786 (C) 792D-E (See also University of KwaZulu-Natal v Makgoba (17124/2005) [2009] ZAKZDHC 28 (17 July 2009) 31)) the court held that section 13 can only be relied upon if the provisions contained in the trust deed results in the consequences stated in the section and not to fill lacunae in a trust deed. Section 13 can also not be used if the consequences complained of stemmed from an application of common law principles and not a provision in the trust deed, and if no application was brought in terms of section 13 (Potgieter v Potgieter NO 2012 (1) SA 637 (SCA) 649I-650B; See also Pascoal $v$ Wurdeman (2012 (3) SA 422 (GSJ) 429C-E) where the court held that in the absence of an application brought in terms of section 13 , it is not empowered to read a term into the trust deed).

Ziqula $v$ Jansen van Rensburg ([2010] ZAECGHC 116 (25 November 2010)) dealt with an application to terminate the trust. It was confirmed that at common law, a court is not empowered to terminate a trust, but can do so in terms of section 13 of the TPCA (Ziqula $v$ Jansen van Rensburg supra 8). It was noted that in the past, courts exercised their discretion by taking into account changed economic conditions and have allowed the variation of trust provisions where the original scheme was rendered practically impossible, utterly unreasonable or simply impossible to carry out (Ziqula $v$ Jansen van Rensburg supra 9). However, the more recent approach seeks to preserve the fundamental aim of the founder in changed circumstances as opposed to adhering to a literal implementation which has been overreached by events (Ziqula $v$ Jansen van Rensburg supra 9). In casu, the application to terminate the trust was successful as the primary objective of the trust was incapable of being carried out due to the attitude of the trustees (Ziqula $\checkmark$ Jansen van Rensburg supra 12).

Section 13 contains both subjective (the founder's lack of foresight or contemplation) and objective criterion (the hampering of the trust object, or prejudice to the interests of beneficiaries, or conflict with the public interest) that must be satisfied before an application in terms of this section will be successful (Cameron et al Honoré's South African Law of Trusts 517; Du Toit South African Trust Law 54). 


\section{$3 \quad$ Charitable trusts}

Charitable trusts are usually created with the achievement of an impersonal object in mind, so that a founder need not appoint ascertained or ascertainable beneficiaries. With such trusts, the object is to benefit the general public or a defined section of the community. In other words, the object of the trust is to give charity and not to benefit individual beneficiaries (Cameron et al Honoré's South African Law of Trusts 161; Du Toit South African Trust Law 190; Olivier Trust Law and Practice (1990) HAUM Tertiary: Pretoria 131-132).

Although the composition of a "charitable purpose" cannot be demarcated exhaustively, a disposition for charitable purposes must exhibit some element of public benefit (De Waal and Schoeman-Malan Law of Succession 5ed (2015) 184; Du Toit South African Trust Law 190). The concept of public benefit was clarified in Ex Parte Henderson, where it was said that public benefit does not necessarily mean conferring a benefit on the community at large (1971 (4) SA 549 (D)). The element of public benefit will be present in a bequest if it is aimed at advancing the interests of a section or group in the community, provided that the section or group is sufficiently large or representative (Ex Parte Henderson supra 554A-B).

\section{$4 \quad$ Constitutional principles}

South African trust law has been adapted not only to accommodate the rights contained in the Bill of Rights constituting Chapter 2 of the Constitution, but also to give effect to constitutional principles generally. However, as the Supreme Court of Appeal in Hofer v Kevitt (1998 (1) SA 382 (SCA) 387C) noted:

"Subject to departure from previous decisions that might be influenced by s39(2) of the Constitution of the Republic of South Africa Act 108 of 1996, it is well known this Court is bound by its own decisions" (Hofer $v$ Kevitt supra 387C).

To the extent that existing common-law principles do not infringe provisions in the Constitution, the doctrine of stare decisis remains applicable. In Potgieter $v$ Potgieter (supra 652A), the Supreme Court of Appeal further confirmed that if recourse can be had to existing common-law principles, a deviation from such principles purely on the grounds of reasonableness and fairness offends the principle of legality, which forms part of the rule of law.

The application of the Constitution is most apparent in respect of charitable trusts, where our courts have attempted to balance the commonlaw rules pertaining to freedom of testation against constitutional and policy considerations based on equality and non-discrimination (See In re Heydenrych Testamentary Trust 2012 (4) SA 103 (WCC); Curators, Emma Smith Educational Fund $v$ University of KwaZulu-Natal 2010 (6) SA 518 (SCA); Ex Parte BOE Trust Ltd 2009 (6) SA 470 (WCC); Minister of Education v Syfrets Trust Ltd 2006 (4) SA 205 (C)). 
The court in Minister of Education $v$ Syfrets Trust emphasised that the concept of public policy, which is now rooted in our Constitution and the fundamental values that it enshrines, changes with time, as social conditions evolve and basic freedoms develop (Minister of Education $v$ Syfrets Trust Ltd supra $218 \mathrm{C}-\mathrm{F} ; 220 \mathrm{~A}-\mathrm{B}$ ). Thus, questions regarding public policy had to be dealt with in terms of the "public policy of today" (Minister of Education $v$ Syfrets Trust Ltd supra 220A) and not that which was in existence when the trust was created. Hence, for the matter at hand, the court sought guidance in the "founding constitutional values of human dignity, the achievement of equality and the advancement of human rights and freedoms, non-racialism and non-sexism" (Minister of Education $v$ Syfrets Trust Ltd supra 219A). The court used the equality test laid down in Harksen $v$ Lane (1998 (1) SA 300 (CC)); For a discussion of the court a quo's decision see University of KwaZulu-Natal $v$ Makgoba (supra) and, after applying the relevant legal principles, held that the disputed provisions limiting trust benefits on the grounds of race, gender and religion (the bursary was limited to non-Jewish males who were of "European descent") unfairly discriminated against a class of persons "who have suffered in the past from disadvantage" because of their race, gender and religion (Minister of Education $v$ Syfrets Trust Ltd supra 222G-223A). The court emphasised, however, that the decision did not mean that the principle of freedom of testation was obsolete or could be ignored. Instead, the decision simply enforced a limitation on freedom of testation that has existed "since time immemorial" (Minister of Education $v$ Syfrets Trust Ltd supra 229E-F). Further, the decision did not mean that all clauses in wills or trust deeds that differentiate between groups of people are invalid per se (Minister of Education $v$ Syfrets Trust Ltd supra 229F).

In Minister of Education $v$ Syfrets Trust Ltd, the court was willing to accept that the common-law right to freedom of testation is protected by section 25 of the Constitution (Minister of Education v Syfrets Trust Ltd supra 216C-D). However, notwithstanding such constitutional protection, freedom of testation has never been absolute and has always been subject to various common law and statutory restrictions (Minister of Education $v$ Syfrets Trust Ltd supra 217I-H). Under the common law, freedom of testation can be limited on the basis of public policy (Minister of Education $v$ Syfrets Trust Ltd supra $218 \mathrm{~A})$.

In Curators, Emma Smith Educational Fund v University of KwaZulu-Natal (2010 (6) SA 518 (SCA)), the Supreme Court of Appeal pronounced that the constitutional imperative to remove racially restrictive clauses in an educational trust that are in conflict with public policy must take precedence over freedom of testation. This finding was buttressed by the fundamental values of our Constitution and the constitutional injunction to transcend our racially divided past (Curators, Emma Smith Educational Fund $v$ University of KwaZulu-Natal supra 528G-529A).

Notably, the court in Ex Parte BOE Trust Ltd (supra 475C) emphasised that discriminatory provisions in trusts that are aimed at redressing past injustices based on gender and race are legitimate and thus do not amount to unfair discrimination. The court took cognisance of the fact that the racially restrictive provision in question, which limited the bursary bequest to white females was a means by which the testatrix sought to avoid the skills of 
white graduates being lost through emigration (Ex Parte BOE Trust Ltd supra 475D-F). Furthermore, the trust was created well into the new constitutional dispensation which indicated to the court that the testatrix was aware that the disputed provision may not be carried out (Ex Parte BOE Trust Ltd supra 477B-C). However, the bursary bequest was impossible to implement, not because of the provision itself, but because of the attitude of the relevant universities that refused to participate in the selection of bursary recipients (Ex Parte BOE Trust Ltd supra 477C-D). The testatrix had made provision for alternative beneficiaries should it not be possible to implement the bequest (Ex Parte BOE Trust Ltd supra 477D). As courts cannot rewrite wills, effect had to be given to the testatrix's right of freedom of testation by benefiting the alternative beneficiaries whom she had identified (Ex Parte BOE Trust Ltd supra 477I-J).

The matter was taken on appeal in In re BOE Trust Ltd (2013 (3) SA 236 (SCA)). In confirming the court a quo's decision, the Supreme Court of Appeal went further by holding that a failure to implement a testator's right to freedom of testation, when it can be done, would infringe the fundamental right to dignity (In re BOE Trust Ltd supra 243G). Furthermore, the rights to dignity and property demand that the wishes of a testator first be established before an enquiry is conducted into whether or not there is a rule that prevents a court from giving effect to freedom of testation (In re BOE Trust Ltd supra 244B-C).

Although it is not a case which was heard under the new constitutional dispensation, the court in Ex Parte President of the Conference of the Methodist Church of Southern Africa NO: in Re William Marsh Will Trust (1993 (2) SA 697 (C)) considered social and economic changes in finding that the words "white destitute children" contained in a testamentary trust violated public policy, inter alia, because the number of white children in need of the homes established under the trust decreased as the white population became more affluent (Ex Parte President of the Conference of the Methodist Church of Southern Africa: in Re William Marsh Will Trust supra 703B).

These cases illustrate the willingness of South African courts to adapt trust principles to accommodate social changes, to the extent that such accommodation accords with the fundamental values of the Constitution. Although the Minister of Education $v$ Syfrets Trust Ltd and Curators, Emma Smith Educational Fund $v$ University of KwaZulu-Natal judgments illustrate that, more often than not, the right to equality will take precedence over the right to freedom of testation, the appeal case in In re BOE Trust Ltd warns that a failure to give effect to a testator's wishes, when it is possible to do so, will infringe the right to dignity.

The above analysis illustrates the judicial attention from a constitutional perspective that trusts have attracted in recent years, as exclusionary provisions contained in particularly charitable testamentary trusts were challenged on constitutional and policy grounds. These challenges required the courts to strike a balance between freedom of testation on the one hand, and the other constitutional rights alleged to be at stake on the other hand. 


\section{$5 \quad$ Misinterpretation of Section 13}

The problems regarding the courts' engagement with section 13 applications of the above nature did not relate to the actual trusts themselves, but rather to the court's interpretation of section 13 of the TPCA where this section was invoked to effect variations to the trust instruments in issue.

Section 13 was used for the first time in Ex Parte President of the Conference of the Methodist Church of Southern Africa NO: in re William Marsh Will Trust (supra) wherein the applicant applied for an amendment of the trust provisions, to inter alia, have the word "white" removed from the testator's will. The court granted the application, finding that both the abovementioned criteria were met in that the founder neither contemplated nor foresaw that his charitable act would be hampered by a shortage of persons eligible to benefit from the trust because of the qualification that he stipulated and because the provision conflicted with the public interest (Ex Parte President of the Conference of the Methodist Church of Southern Africa NO: in Re William Marsh Will Trust supra 702F-703J).

The judgment elicited criticism as far as the court's interpretation of the relevant criteria was concerned. Van der Spuy ("Ex parte President of the Conference of the Methodist Church of Southern Africa NO: In re William Marsh Will Trust 19933 SA 697 (K)" 1993 De Jure 447 451-452) argues that the court misconstrued the testator's benevolence by allowing access to children of all races, while the trust deed limited it to white children only (see also Du Toit South African Trust Law 55). Also, that the testator provided that the excess income be used for institutions such as hospitals was indicative that he had foreseen that the financial requirements of the home would vary (Van der Spuy 1993 De Jure 452-453; Du Toit South African Trust Law 55). Insofar as the objective criterion was concerned, the author asserts that the court should have established whether the consequences of the trust provisions were in conflict with the public interest and not whether the provisions were contrary thereto. Moreover, the court interpreted "public interest" to include the community at large, which according to the author is incorrect as such an interpretation would result in any charitable trust which caters for a particular race; religion; et cetera being in conflict with public interest (Van der Spuy 1993 De Jure 454-455). Du Toit (South African Trust Law 55) on the other hand, holds the view that the case illustrates a judicial willingness to invoke policy considerations when such court intervenes in charitable dispositions by testators. However, he notes that the concerns raised by Van der Spuy regarding provisions based on race, religion et cetera are valid especially in light of the right to freedom of testation, which has been accepted, but not yet authoritatively decided, as forming part of the right to property as provided in section 25 of the Constitution (Act 108 of 1996; see also Minister of Education v Syfrets Trust Ltd supra 216C-D; Keightley Annual Survey (2006) 491).

In University of KwaZulu-Natal v Makgoba (supra) the applicants applied for the words "European", "British" and "Dutch South African" to be removed from the provisions of the trust deed. As far as the subjective criteria, the court highlighted that the founder would not have appreciated that his bequest became an embarrassment to the institution he nominated to 
administer it nor that he would be branded a racist or discriminatory, considering that his aim was to help the poor and needy (University of KwaZulu-Natal v Makgoba supra 35-36). With regard to the objective inquiry the focus was on the public interest which the court held was comprehensively tied up with the right to freedom of testation and the equality debate. In this regard, the court stated that there is a significant public interest in carrying out a testator's desires and thus, charitable trusts should be benevolently interpreted and upheld as far as possible (University of KwaZulu-Natal v Makgoba supra 41). Regarding the application of the Constitution to such bequest, it was held that the provisions of the Constitution apply horizontally. However, the problems nevertheless arise because of the absence of national legislation governing the principles enacted (University of KwaZulu-Natal v Makgoba supra 54). Moreover, the necessity to develop the common law finds application when it is found to be inconsistent with the Constitution. An inquiry into such a matter requires development as far as the interpretation of the "nature" of the public interest as set out in section 13 (University of KwaZulu-Natal v Makgoba supra 55). The financing of education is primarily a government function and funding from founders as in casu supplements the government's role. Thus, if donors were allowed to allocate their funds in a discriminatory manner it would not be in the public interest (University of KwaZulu-Natal v Makgoba supra 79). The court thus found in favour of the applicants.

$\mathrm{Du}$ Toit argues that this case is once again an illustration of a situation where a court failed to apply the criteria of section 13 correctly ("Application for the Variation of Testamentary Trust Provisions" 20093 Juta's Quarterly Review). The problem that has arisen is that courts interpret the subjective criterion as requiring an unforeseen change in circumstances, whereas, it in fact requires that a trust provision "occasions" unforeseen circumstances (Du Toit 2009 July-September JQR 3). An easier approach would be to rely on the common-law power of courts to vary trust provisions (Du Toit 2009 July-September JQR 3), which power he says is being developed by our courts by implementing the Constitution (See Minister of Education $v$ Syfrets Trust Ltd supra). Nevertheless, this approach has also been criticised. It has been argued that if the provision can still be implemented, then it should remain intact and regard should be given to the time period and the circumstances wherein the trust was created (Van der Westhuizen and Slabbert "Wysiging van die Bepalings van 'n Liefdadigheidstrust" 2007 TSAR 209; 212).

Curators, Emma Smith Educational Fund v University of KwaZulu-Natal (supra) involved an appeal against the above decision. The question sought to be answered was whether the bequest could stand in its racially exclusive form (Curators, Emma Smith Educational Fund v University of KwaZuluNatal supra $519 \mathrm{I}-\mathrm{J}$ ). In relation to section 13 , the SCA held that subsections (a) and (c) applied to the matter, as the racially restrictive nature of the Fund prevented the realisation of the testator's intentions and was in conflict with the public interest. The SCA thus agreed with the court a quo's decision to remove the racially restrictive provision (Curators, Emma Smith Educational Fund $v$ University of KwaZulu-Natal supra 528C-D). 
As far as the argument that it would limit the founder's right to freedom of testation if the restrictive provision is removed, the court held that the constitutional imperative to remove restrictions that conflict with public policy must take precedence over freedom of testation particularly given the fundamental values of our constitution and the constitutional imperative to move away from our racially divided past. It would thus, not amount to an unlawful deprivation of property (Curators, Emma Smith Educational Fund $v$ University of KwaZulu-Natal supra 528F-529A). The appeal was therefore dismissed.

The time period within which the trust was created was a vital factor considered in Ex Parte BOE Trust Ltd (supra) where an application in terms of section 13 was brought to inter alia have the word "white" removed from the trust provision (See also In re Heydenrych Testamentary Trust supra $104 \mathrm{H})$ which dealt with three charitable testamentary trusts which were attacked on the basis of certain discriminatory provisions regarding the potential beneficiaries of such funds. The applicant sought to have provisions which discriminated on the grounds of race and colour deleted. The court highlighted that it is trite law that a court has no general power to vary the terms of wills, contracts or other instruments other than through the exceptions provided in terms of the common law, a direct application of the Constitution and section 13 of the TPCA (In re Heydenrych Testamentary Trust supra 107E-F). One of the main issues was whether the two jurisdictional facts were present for the court to intervene in terms of section 13 (108A-B). Relying on the time frame within which the trusts were created, the court found that the provisions of the trusts brought about consequences that the founders of the trusts did not contemplate or foresee. Furthermore, the bequests were not only in conflict with the Constitution, but against public policy as well (In re Heydenrych Testamentary Trust supra 108A-111I)). In Ex Parte BOE Trust Ltd, the Universities that were entrusted to pay out these amounts refused to do so for as long the discriminatory wording was in place. Regarding the variation of trust provisions, the court said that finding a provision in a will or trust instrument that is contrary to public policy does not per se give the court the power to vary the provision as it deems fit (Ex Parte BOE Trust Ltd supra 476F). In order for a court to intervene, the court must form an opinion that the provision has brought about consequences that the founder of the trust did not contemplate or foresee. In the absence of such opinion, a court is not empowered to depart from the directions of the founder other than by striking down a severable provision or the whole bequest as "it is the jurisdictional fact upon which the power to vary (or terminate or grant any other order) rests" (Ex Parte BOE Trust Ltd supra 476F-H).

It was acknowledged that a shift in public policy occurred during the time that the trust was created and when the court was called upon to consider the matter. However, the testatrix's will was nevertheless executed eight years into the constitutional dispensation (Ex Parte BOE Trust Ltd supra $476 \mathrm{H}-477 \mathrm{~B})$. It could therefore not be suggested that she was unaware of the changes that came about after 1994, nor was the case made that circumstances unforeseen by the testatrix had any effect on the implementation of the bursary bequest (Ex Parte BOE Trust Ltd supra $477 \mathrm{~B}-\mathrm{C})$. Instead, what rendered the implementation of the bursary bequest 
impossible was the attitude of the relevant Universities' refusal based on their belief that the bequest was contrary to public policy (Ex Parte BOE Trust Ltd supra 477C-D). It was also evident that the testatrix indeed foresaw that her bequest might become impossible to carry out and thus made provision in the event that this arose (Ex Parte BOE Trust Ltd supra 477D).

Although it was argued by the trustees that it would be prudent for the primary purpose of the trust to be carried out by effecting the amendment as sought the court held that the request was impermissible as courts are not free to rewrite testamentary dispositions simply because the trustees sought that this be done (Ex Parte BOE Trust Ltd supra $477 \mathrm{H}-478 \mathrm{~A}$ ). The right to freedom of testation implies that effect must be given to the express wishes of the testator, except insofar as the requirements in section 13 are met. Only in the absence of the relevant jurisdictional fact, is a court empowered to declare a provision in the trust instrument void as being against public policy (Ex Parte BOE Trust Ltd supra 478A-B). The application was thus dismissed.

The matter was taken on appeal in In re BOE Trust Ltd (supra). In confirming the court a quo's decision, no reference was made to section 13 when discussing the constitutional rights at stake.

\section{$6 \quad$ Evaluation}

While there has been criticism of how the courts have interpreted the subjective and objective criterion, the provision does not appear to cause practical difficulties. The courts furthermore rely on the rights contained in the Bill of Rights when reaching their decisions. It is commendable that the right to freedom of testation, which appears to be trumped more often than not, was protected by considering the time frame within which the trust was created. This illustrates a willingness by the courts to strike a balance between the right to freedom of testation and any other constitutionally protected rights that might be at stake. In any event, the facts of the case will determine whether or not the requirements of section 13 have been met, with reference to the rights contained in the Bill of Rights. The provision should thus remain intact, albeit in amended form, more so as it empowers courts to not only vary trust provisions, but to terminate a trust as well, which it is not empowered to do in terms of the common law.

As mentioned earlier, Du Toit remarks that the courts, when section 13 has been invoked for the aforementioned purpose, appear to interpret the section's subjective criterion as requiring an unforeseen change in circumstances subsequent to the execution of the will in question, whereas it in fact requires that a trust provision occasions unforeseen consequences (2009 July-September JQR 3). He therefore argues, reliance should be placed on the common-law power of courts to vary trust provisions (Du Toit 2009 July-September JQR 3) which power is being developed by our courts as they implement the Constitution (See Minister of Education $v$ Syfrets Trust Ltd supra). Van der Westhuizen and Slabbert deliver even sterner criticism when they argue that, if a testamentary charitable trust provision 
can be implemented, it should remain intact, with regard being had to the time period and the circumstances in which the trust was created (2007 TSAR 209; 212).

Curators, Emma Smith Educational Fund v University of KwaZulu-Natal illustrate some of the foregoing concerns. It dealt with an appeal against, inter alia, the court of first instance's striking-out of racial limitations from an educational fund established under a testamentary trust (Curators, Emma Smith Educational Fund $v$ University of KwaZulu-Natal supra). In relation to section 13, the Supreme Court of Appeal found that the racially restrictive nature of the trust prevented the realisation of the testator's intentions and that "[t]his is due to dramatically changed circumstances from the time that the will was made" (Curators, Emma Smith Educational Fund v University of KwaZulu-Natal supra 521I). The court's emphasis on changed circumstances underlines Du Toit's criticism, whereas Van der Westhuizen and Slabbert would likely have wanted the testator's will to remain unaltered because the court admitted that amounts had been paid from the trust, albeit lower than what the trust could afford (Curators, Emma Smith Educational Fund $v$ University of KwaZulu-Natal supra $521 \mathrm{H}$ ). The Supreme Court of Appeal furthermore appears to have placed far greater emphasis on the fact that the racial restrictions contravened the public interest (as part of s 13's objective criterion) and, it is submitted, paid inadequate attention to the section's subjective criterion in dismissing the appeal on this point against the lower court's judgment.

It is evident from the above discussion that many of the problems associated with section 13 of the TPCA do not stem from the provision itself, but rather from the court's interpretation and application of the criterion which it stipulates. Courts have relied upon constitutional changes to hold that circumstances have arisen which the founder did not contemplate or foresee; whereas they should be ascertaining whether the provision itself has brought about circumstances which the founder did not contemplate or foresee. An unfortunate consequence of this misinterpretation is that freedom of testation, more often than not, may be superseded by the other rights in question.

\section{$7 \quad$ Recommendation}

It is submitted that courts should follow the approach adopted by the Supreme Court of Appeal in In re BOE Trust Ltd. This approach requires that a court begins by establishing the wishes of the testator, thereby giving effect to the rights to dignity and property. Thereafter, an enquiry must be conducted to determine whether or not there is a rule that prevents the court from giving effect to freedom of testation (In re BOE Trust Ltd supra 244B-C), by taking into account the time period and the circumstances in which the trust was created (Van der Westhuizen and Slabbert 2007 TSAR $209 ; 212$ ). For the courts to utilise this approach effectively, it is suggested that section 13 be amended to avoid the criticism alluded to above. An amended section 13 might read as follows:

"If a trust instrument contains any provision which:

a) hampers the achievement of the objects of the founder; or 
b) prejudices the interests of beneficiaries; or

c) is in conflict with the public interest

[due to a change in circumstances, which in the opinion of the court the founder of a trust did not contemplate or foresee], the court may, on application of the trustee or any person who in the opinion of the court has a sufficient interest in the trust property, delete or vary any such provision or make in respect thereof any order which such court deems just, including an order whereby particular trust property is substituted for particular other property, or an order terminating the trust."

The foregoing proposed amendment could be challenged as being merely declaratory of the common law (The SALRC was opposed to the proposed Act including provisions which merely confirms the common-law position. Regardless of this opposition, both ss 9 and 12 of TPCA are statutory provisions which are merely declaratory of the common law). However, section 13 of the TPCA confers wider powers on courts than the common law to amend trust provisions (Cameron et al Honoré's South African Law of Trusts 517; Du Toit South African Trust Law 54). Furthermore, the proposed amendment will be in line with how the Supreme Court of Appeal in Emma Smith ostensibly interpreted the section's subjective criterion (A similar interpretation was ostensibly followed in In re Heydenrych Testamentary Trust supra). Also, the amendment will enable courts to develop constitutional principles in respect of section 13 along lines similar to the development currently taking place in respect of the common law power of courts to vary trust instruments (See Minister of Education $v$ Syfrets Trust Ltd supra).

\section{$8 \quad$ Conclusion}

While section 13 of the TPCA does not cause practical difficulties, the above analysis illustrates that our courts have not interpreted the criterion in section 13 correctly. To avoid similar criticism in future, it is submitted that the solution lies in amending section 13 in a manner that gives effect to how our courts are currently interpreting the section. The amendment will go a long way in not only preventing the misinterpretation of the criterion, but will also enable our courts to strike a proper balance between the constitutional rights at stake in charitable bequests which allegedly discriminate against potential beneficiaries. 